\title{
Flow cytometry: a new method for characterization of differ- ential ingestion, digestion and egestion by suspension feeders
}

\author{
Terry L. Cucci ${ }^{1}$, Sandra E. Shumway ${ }^{1,2}$, Richard C. Newell ${ }^{3}$, \\ Rhonda Selvin ${ }^{1}$, Robert R. L. Guillard ${ }^{1}$ \& Clarice M. Yentsch ${ }^{1}$ \\ ${ }^{1}$ Bigelow Laboratory for Ocean Sciences, McKown Point, West Boothbay Harbor, Maine 04575, USA \\ 2 Department of Marine Resources, McKown Point, West Boothbay Harbor, Maine 04575, USA \\ ${ }^{3}$ Royal Society Senior Research Fellow, Institute for Marine Environmental Research, Plymouth, PL1 3DH, United Kingdom
}

\begin{abstract}
Whether filter-feeding organisms can (1) select, (2) preferentially ingest, and/or (3) preferentially digest suspended particles, is of major importance to our understanding of material flow through marine systems. Investigation has until recently been limited by lack of techniques that can distinguish quantitatively between different particles of the same size. We demonstrate here the ability to distinguish algal food particles quantitatively, even when they are of a similar size, by the detection of their fluorescent photosynthetic pigments using a flow cytometer. The usefulness of this technique is illustrated by experiments on the mussel Mytilus edulis fed a mixed algal diet. In these experiments, a cryptomonad was digested in preference to a dinoflagellate and a
\end{abstract} diatom

The study of particle selection by organisms, ranging in size from small heterotrophic flagellates and ciliates of a few micrometers to adult bivalve molluscs, has been hampered in the past by technical difficulties. It was originally inferred from morphology and direct observation of intact animals, that suspension-feeding bivalves were capable of particle selection (Jørgensen 1966, Owen 1966). Subsequent studies were greatly assisted by use of the Coulter Counter which allowed quantitative estimates of filtration rate and of size selective particle retention (Sheldon \& Parsons 1967 , Stuart \& Klumpp 1984). Such work suggested that many bivalves select particles on the basis of size alone (Foster-Smith 1975a, b, Winter 1978). Recent studies suggest, however, that at least 11 species of bivalves can select algae preferentially from a mixture of algae and silt particles (Kiørboe et al. 1980, Kiørboe \& Mohlenberg 1981, Newell \& Jordan 1983).

Most of these studies examine the question of selection of nutritive particles from inorganic particles of a similar size. Major limitations of the Coulter Counter technique are: (1) particles occupying the same volume range cannot be distinguished simultaneously;
(2) even though only $0.5 \mathrm{ml}$ is actually sampled per analysis, relatively large volumes $(\sim 10$ to $20 \mathrm{ml})$ of culture liquid are required to maintain the orifice within the sample. A standard protocol is described here in which algae from several different chromatic groups (i.e. having different photosynthetic pigment complements) can be detected simultaneously during flow cytometry analyses (FCM) (Yentsch et al. 1985) using small volumes of liquid for the measurement. As a result, particles of similar size but of different optical properties can be analyzed quantitatively.

Fluorescence derived from 1 particle is split by a $590 \mathrm{~nm}$ dichromic mirror and is received by 2 photomultiplier tubes. One receives a wavelength spectral region $>630 \mathrm{~nm}$ such as would result from chlorophyll emission; the other, shorter wavelengths $(530$ to $560 \mathrm{~nm}$ ) as would result from phycoerythrin and phycocyanin emission. Several thousand particles can be analyzed per minute, yet a sample volume of only 1 to $2 \mathrm{ml}$ is required for an analysis of as many as $10^{4}$ particles.

Analysis of bivariate 3-decade log scale plots of fluorescence intensity shows that there are at least 4 useful regions within the plots in which various microalgae can be distinguished by their fluorescence properties. These include (1) green unicells with chl a and chl $b$, and diatoms with chl $a$ and chl $c$ plus fucoxanthin; (2) dinoflagellates, with chl $a$ and chl $c$ plus peridinin and which give more fluorescence than 1; (3) cryptomonads which have both phycoerythrin or phycocyanin plus chlorophyll fluorescence; (4) cyanobacteria which have predominantly phycoerythrin and phycocyanin fluorescence (although they also have chl a). Detailed discussion of the usefulness of algal fluorescence spectral signatures is given elsewhere (Yentsch \& Yentsch 1979). Clones having identi- 
cal fluorescence spectra and intensity responses cannot be utilized simultaneously. In addition, bacteria can be stained and incorporated into mixed-resource grazing experiments.

Mytilus edulis from the same spatfall and of approximately $60 \mathrm{~mm}$ shell length were maintained at $8^{\circ} \mathrm{C}$ in running seawater at West Boothbay Harbor. They were held in $0.7 \mu \mathrm{m}$ filtered seawater for $24 \mathrm{~h}$ prior to use to purge their digestive tracts, and were then placed in 31 glass vessels with 21 of algal culture mixtures. Control algal cultures were left without mussels to correct for algal cell division during the course of the experiment. Clonal phytoplankton cultures were grown at $15^{\circ} \mathrm{C}$ under a $14 / 10$ h light-dark cycle on $\mathrm{F} / 2$ medium. Three clones were equally mixed to obtain a final cell density approximating natural phytoplankton levels of $10^{4}$ cells $\mathrm{ml}^{-1}$ and were analyzed in a Coulter EPICS V Flow Cytometer/Sorter with a single argon ion $5 \mathrm{~W}$ laser using an excitation wavelength of $514 \mathrm{~nm}$ with a power of $1,000 \mathrm{~mW}$. The events (number of cells) registered met gate criteria based on red fluorescence (chlorophyll), therefore only algal cells were analyzed. Based solely on pigment fluorescence intensity, a total of 10,000 cells were analyzed for each sample, with the total number partitioned among the 3 clones. All bivariate histograms are on the same scale and show number of events (cells analyzed) plotted with increasing relative phycoerythrin fluorescence (X-axis) and increasing relative chlorophyll fluorescence ( $Y$-axis).

A major advantage of the FCM approach is the ability to distinguish between cells of nearly equal dimensions. This is shown in the experimental results summarized in Fig. 1. Three different species were presented to mussels. These were the spindle-shaped diatom Phaeodactylum tricornutum (clone Phaeo), which is ca 2.5 to $3.5 \times 12$ to $23 \mu \mathrm{m}$ in size; the dinoflagellate Prorocentrum sp. (clone Exuv.), ca 5 to
$6.15 \times 8.75$ to $12.5 \times 15 \mu \mathrm{m}$; and the cryptomonad flagellate Chroomonas salina (clone $3 \mathrm{C}$ ), 6.25 to $7.5 \times 8.75$ to $12.5 \mu \mathrm{m}$.

Fig. 1 shows the relative populations for the 3 components at times zero (A), 15 min control (B), and 15 min experimental (C) vessels. The mean time required to analyze $10^{4}$ cells from the $15 \mathrm{~min}$ experimental vessel was $478 \mathrm{~s}$ compared with only $346 \mathrm{~s}$ in the control, showing that after $15 \mathrm{~min}$, there were fewer algal cells in suspension within the experimental vessels and, therefore, food was consumed during the experiment. In this and other (unpubl.) experiments there was no differential clearance of cells ranging in size from those used here to cyanobacterial cells (Synechococcus sp.) of ca $1 \mu \mathrm{m}$ size.

An important advantage of the FCM technique is that differential digestion and egestion can be detected. True feces represent material which has been ingested and passed through the gut. Pseudofeces are formed by mussels when filtered particles are consolidated with mucus and rejected prior to ingestion. Examination of feces of mussels in our experiments, using epifluorescence microscopy, showed intact algal cells suggesting that at least some components of the ingested food pass through the gut intact.

After completion of the feeding experiments, mussels were transferred to $2 \mathrm{l}$ vessels containing filtered seawater $(0.7 \mu \mathrm{m}$ Gelman glass fiber) and left for $4 \mathrm{~h}$, after which feces were collected. The material was gently sonicated for $1 \mathrm{~min}$ and passed through a $55 \mu \mathrm{m}$ Nitex net to remove any remaining clumps prior to FCM analysis. The results of such analyses are summarized in Fig. 2. Cryptomonads were absent from the feces, while the diatom and dinoflagellate evidently passed through the gut without significant digestion. In contrast, while having similar and higher propor-

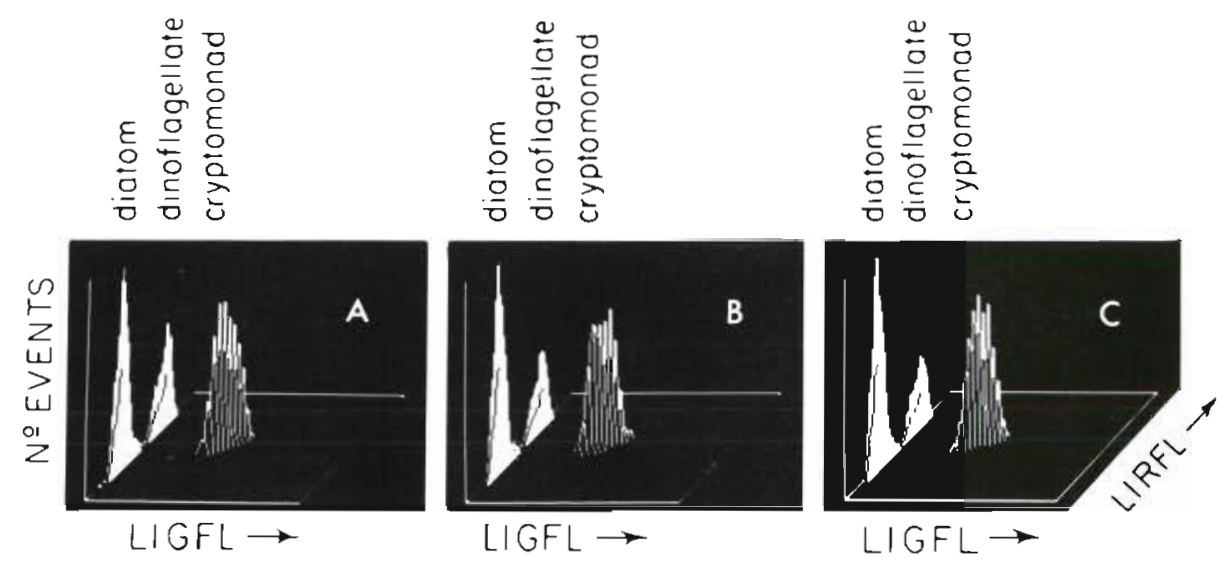

Fig. 1. Bivariate histogram plots of number of events (cells analyzed) and $X=\log$ integrated green fluorescence (LIGFL) (fluorescence due to phycoerythrin) vs $Y=\log$ integrated red fluorescence (LIRFL) (fluorescence due to chlorophyll). Mytilus edulis grazing on algal mixture of a diatom (clone Phaeo), a dinoflagellate (Exuv), and a cryptomonad (3C) over 15 min time course.

(A) initial; (B) control at $15 \mathrm{~min}$; (C) experiment at $15 \mathrm{~min}$ 
tions of the dinoflagellate and diatom, respectively, than the initial algal mixture, the pseudofeces also contained the cryptomonad species.
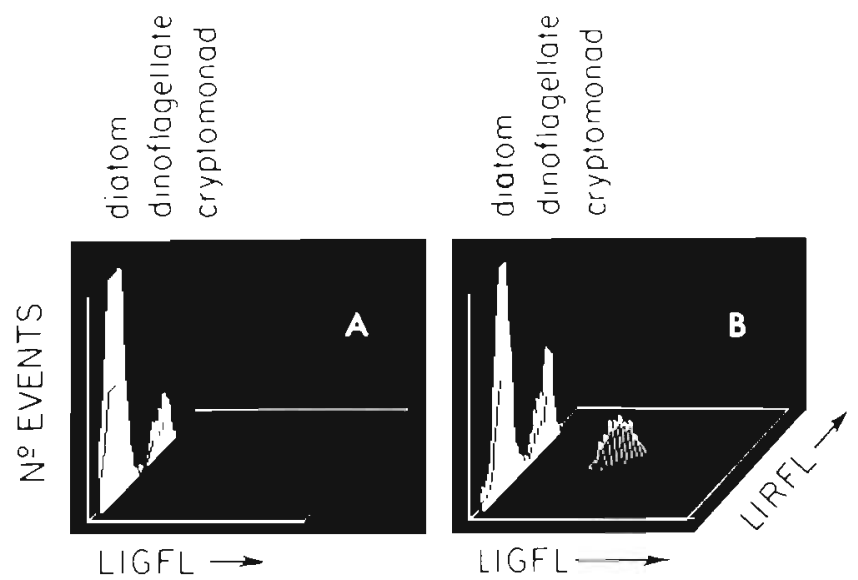

Fig. 2. Bivariate histogram plots of number of events (cells analyzed) and $\mathrm{X}=\log$ integrated green fluorescence (LIGFL) vs $\mathrm{Y}=\log$ integrated red fluorescence (LIRFL) of (A) feces and (B) pseudofeces from Mytilus edulis following $15 \mathrm{~min}$ feeding on clones Phaeo, Exuv and $3 C$. In (A) the 10,000 events analyzed are partitioned basically between the diatom and dinoflagellate, thus the diatom peak is off scale

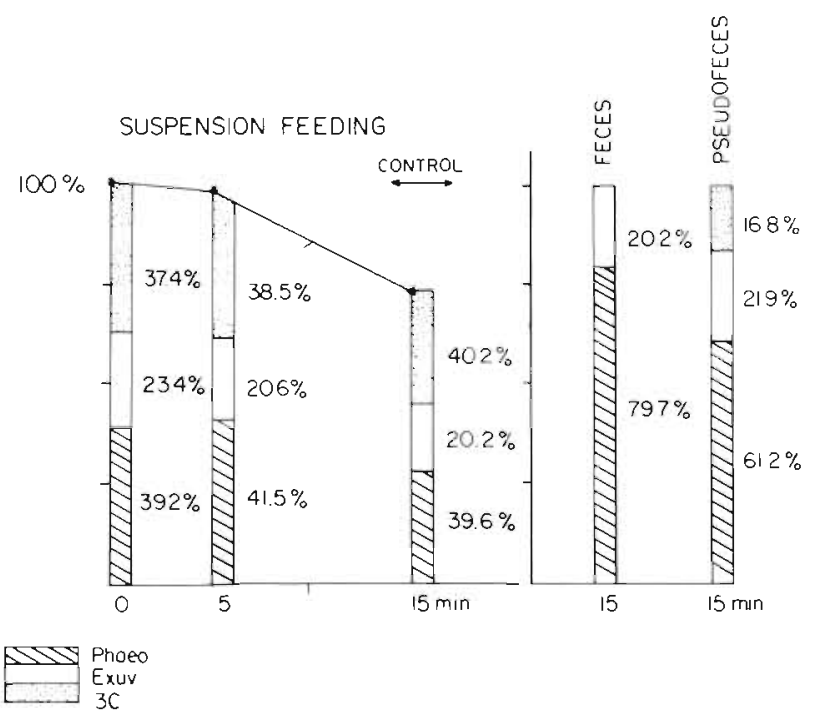

Fig. 3. Summary of suspension-feeding experiment using clones Phaeo (the diatom Phaeodactlyum tricornutum), Exuv (the dinoflagellate Prorocentrum sp.) and 3C (the cryptomonad Chroomonas salina) as food particles and Mytilus edulis as suspension feeder. Analysis of culture mixtures were run at zero time $\left(n=5\right.$; total $5.39 \times 10^{4}$ cells ml-1), corresponds to Fig. $1 \mathrm{~A} ; 5 \mathrm{~min}$ ( $\mathrm{n}=5$; total of $5.3 \times 10^{4}$ cells $\left.\mathrm{ml}^{-1}\right)$; and $15 \mathrm{~min}\left(\mathrm{n}=6\right.$; total of $3.92 \times 10^{4}$ cells $\left.\mathrm{ml}^{-1}\right)$, corresponds to Fig. $1 \mathrm{C}$. The feces $(n=4)$ and pseudofeces $(n=1)$ were analyzed following egestion subsequent to a $15 \mathrm{~min}$ feeding exposure time. These correspond to Fig. $2 \mathrm{~A}$ and $\mathrm{B}$, respectively. Count at time zero is taken as $100 \%$. Controls remained the same after the $15 \mathrm{~min}$ experimental time
The cell numbers obtained by direct cell counts and the relative numbers of cells of each clone obtained by FCM are summarized in Fig. 3. This shows the important distinction between cell clearance, which in this cell size range was similar for the diatom, the dinoflagellate, and the cryptomonad, and the differential absorption or utilization of one component or another of a mixed food supply during passage through the gut.

The complex size overlap presented by natural particles in the sea once limited the scope and design of experiments on the differential utilization of particulate matter. We can now take advantage of fluorescence and light-scatter characteristics of particles to examine differential use by consumer organisms of food resources comprised of groups having similarsized cells with different chromatic signatures. Even bacteria can be used experimentally, provided they have been stained with fluorescent materials prior to use so that bacterial fluorescence can be distinguished from algal fluorescence. Flow cytometry thus presents a potentially manageable, sensitive and unified approach to the study of interrelated problems of particle selection, food preferences, material flow, and marine organisms.

Acknowledgements. We thank Carter Newell at Great Eastern Mussel Farms, Damariscotta, Maine, for mussels. This work was supported in part by NSF grants OCE-82-13567 and NA-82-FA-C-00043, ONR grant N00014-81-C-0043, The Maine Department of Marine Resources and the State of Maine. This is Bigelow Laboratory for Ocean Sciences contribution number 84008 .

\section{LITERATURE CITED}

Foster-Smith, R. L. (1975a). The effect of concentration of suspension and inert material on the assimilation of algae by three bivalves. J. mar. biol. Ass. U.K. 55: 411-418

Foster-Smith, R. L. (1975b). The role of mucus in the mechanism of feeding in three filter-feeding bivalves. Proc. malac. Soc. Lond. 41:571-588

Jorgensen, C. B. (ed.) (1966). Biology of suspension feeding Pergamon Press, Oxford

Kiørboe, T., Møhlenberg, F. (1981). Particle selection in suspension-feeding bivalves. Mar. Ecol. Prog. Ser. 5: 291-296

Kiørboe, T., Møhlenberg, F., Nohr, O. (1980). Feeding, particle selection and carbon absorption in Mytilus edulis in different mixtures of algae and resuspended bottom material. Ophelia 19: 193-205

Newell, R. I. E., Jordan, S. J. (1983). Preferential ingestion of organic material by the American oyster Crassostrea virginica. Mar. Ecol. Prog. Ser. 13: 47-53

Owen, G. (1966). Digestion. In: Wilbur, K., Yonge, C. M. (ed.) Physiology of molluscs. Academic Press, New York, p. 53-96

Price, H. J., Paffenhofer, G.-A., Strickler, J. R. (1983). Modes of cell capture in calanoid copepods. Limnol. Oceanogr. 28: 116-123 
Sheldon, R. W., Parsons, T. R. (1967). A practical manual on the use of the Coulter counter in marine research. Coulter Electronics Sales Co., Canada

Stuart, V., Klumpp, D. W. (1984). Evidence for food-resource partitioning by kelp-bed filter feeders. Mar. Ecol. Prog. Ser. 16: 27-37

Winter, J. R. (1978). A review on the knowledge of suspension-feeding in lamellibranchiate bivalves, with special references to artificial aquaculture systems. Aquaculture 13: $1-33$
Yentsch, C. S., Yentsch, C. M. (1979). Fluorescence spectral signatures: The characterization of phytoplankton populations by the use of excitation and emission spectra. J. mar. Res. 37: 471-483

Yentsch, C. M., Cucci, T. L., Phinney, D. A. (1985). Flow cytometry and cell sorting: Problems and promises for biological ocean science research. Proc. Eur. Soc. Biochem. Physiol. (in press)

Accepted for printing on April 6, 1985 